\title{
Yorùbá Primary School Songs: Issues and Lessons for the Younger Generation
}

\author{
Aladesanmi Omobola Agnes \\ Department of Linguistics and Nigerian Languages, Ekiti State University, Ado - Ekiti, Ekiti State, Nigeria

\begin{abstract}
Song is a worldwide phenomenon. It is a short metrical composition intended or adapted for singing, especially in rhymed stanzas. It can be a lyric or ballad. The usage of songs cannot be over emphasized among the people of Yoruba society. There are various ways in which the Yoruba make use of various songs and their society; such songs include festival songs, folktale, political songs, songs of mother of twins, satirical songs among others. In this paper, primary school Yoruba songs will be looked into. It is noted that there are songs that can be categorized as school children songs. These songs are sung during school hours like assembly time, break time, closing hour, and playtime among others. These songs are composed in a way to teach the school children morals, encourage them in their academics and to pass instructional lessons across to them. These songs have gone a long way in building the characters of the pupils.
\end{abstract}

Index Terms - school children, songs, culture, morals, primary school, society

\section{INTRODUCTION}

Song, according to (https://www.marriamwebster.com Monday 16/12/2019) can be defined as the act or art of singing a poetical composition, a short musical composition of words and music. Song is also a melody for a lyric, poem or ballad. Also, a song is a single musical composition that has a melody and, often, words that are sung by a vocalist. The words of a song as a whole are called the lyrics, and they may include verses that tell a tale or more, a story along, and refrains or short phrases repeated at the end of each verse (https://www.dictionary.com Monday 16/12/2019). (Arthur 1819) argued that music is the answer to the mystery of life. The most profound of all the art, it expresses the deepest thought of life. (Àjàyí 1988) also in his view, argued that music has always had a high place in human societies. Among the various ethnic groups in Nigeria, music is an integral and fundamental part of daily activities. It permits every level of traditional life be it social or ceremonial. (Adélékè 2005) asserts that texts of Yorùbá songs have intrinsic beauty, they teach language, history, morality, religion and so on and so forth.

Furthermore, songs as explained by earlier scholars are in different divisions and sub-divisions, some of which were itemized by (Adéjùmọ 2005) and (Adélékè 2005) as festival songs, folklore, political, satirical, lullabies (orin arẹmọ) or the type of song for twins, etc. (Adéjùmọ 2005) further states that types of song are:

\section{Festival, folktales, political, songs of mother of twins, cradle \\ songs, entreaties, interrogative, incantatory, elegiac and satirical}

Our focus in this paper however, shall be on those that are centered on children, especially in the formative years, i.e. primary school years. The researcher is more accustomed with the Yorùbá language and culture, thus data used for the analysis will be Yorùbá songs of primary school children. Such songs as will be explained are sung in the Yorùbá speaking Western Nigeria primary schools as a means of teaching morals, values, history, philosophy, to foster resilient skills in children. It also serves as an encouragement for the pupils to aim higher to pursue academic excellence. Some are also centered on introducing children to Christian faith and its values, while several of them are to give specific moral instructions which are expected of the children to develop with and to grow into morally, spiritually and culturally acceptable future leaders.

Data used in this paper are collected from primary schools in the South-Western states of Nigeria. The recorded songs were transcribed and the data analyzed using the theory of Sociology of literature.

\section{THEORETICAL FRAMEWORK}

Adéyẹmí (2006) explains that a theory is like razor blade that is used to dissect an intellectual enterprise. It can also be said to be a law or principle that guides the assessment of literary work. (Obáfémi 1997) on literary theory observes that:

Theory is the aesthetic of discourse improving disciplines, to achieve a harmony between the artist's vision, knowledge of craft and successful communication. 
Ọáfẹmi's insistence is that, theory serves as an instrument that is being used to proffer in-depth explanation to a literary work. Hence, the theory that we consider adequate for the analysis of this work is the theory of Sociology of Literature.

\section{SOCIOLOGY OF LITERATURE}

Sociology of Literature is a fusion of two disciplines; Sociology and Literature. In general sense, sociology is the science of social relationships as well as the consequences of the relationships for social systems and the process of social change (Moore1967). Sociology can also be defined as both the scientific study of society and social behaviour and a method by which ordinary people strive to understand what is happening to them and their society (Ògúnșínà 2006). Literature on the other hand is concerned with man and his society. It is an art composed of words in such a way that it proffers entertainment, enlightenment and relaxation. It attempts to develop, elevate, expand and transform the experience of its audience. Literature functions as a continuing symbolic criticism of social values. Literature seeks to investigate man and his behaviour in the society, his knowledge of himself and the universe in which he finds himself. Literature according to (Ògúnșínà 1987) is a part and product of the society.

Sociology of literature therefore, is an attempt to understand the interrelationship between literature and society. It postulates that a work of art does not exist in isolation and should not be studied as such. This is because works of art are not independent of the society that produced them. The language with which a work is composed is the property of the society. Yorùbá songs for instance are products of Yorùbá society; they are created and sung by, and meant for the people in the society. The contents, messages of the songs, language use in the composition and singing are happenings and events in the society. The audience and accompanying musical instruments are also properties of the society. No individual forms his ideas in isolation; he is born into a society and learns his concepts from the social environment.

The Marxist approach to the sociology of literature tries to understand the relations of

Literature to social structure, tries to identify the historic forces that determine the forms and content of literature and seeks to find out how literature in turn reacts on society (Ògúnșínà 2006), (Adéyẹmí 2006).

Sociology of literature is particularly useful in illuminating our knowledge about the social significance of art of which song is one. Since Sociology of literature deals with the inter-relationship between literature and society and that a work of art does not exist in isolation, therefore, this theory will help us highlight in a broader sense appreciation of primary school children's songs, pointing out full understanding and purpose of its creation.

From the point of view of the Sociology of literature, a literary piece is a mine of information about the society that produces it, and thus establishes the fact that work of art either oral or written and the society are inseparable, thus, the adoption of the theory of sociology of literature for our analysis. It is our belief that this approach will appreciate and bring out the beauty and essence of primary school children's songs. It will as well help to explain what the songs are meant to teach or impact on the younger population for the furtherance and betterment of the society.

\section{SONGS AS ARM OF ORAL LiterATURE}

Oral literature according to (Akporobaro 2005) refers to the heritage of imaginative verbal creations, stories, folk beliefs and songs of pre-literate societies which have evolved and passed on through the spoken word from one generation to another. Oral literature is also an important artistic expression that predates written literature in all societies of the world (Afọlábí 2000). According to him, oral literature is, indeed, one of the most effective means of expressing the intellectual, the physical and the spiritual experiences of man in its most natural form. In the Yorùbá society, oral literature serves as the store house of cultural values and moral codes which covers every aspect of Yorùbá life. It is passed down from mouth to mouth from one generation to another pedagogically. Yorùbá oral literature, like its written counterpart, has all the conventional literary genres of drama, poetry and prose. (Ọlátúnjí 1985) and (Ilésanmí 2006) explained further that Yorùbá oral literature is expressed majorly in three modes: speech mode, chanting mode and song mode. These three modes can come together in a repertoire though, most times, rendered separately. Yorùbá chants are classified according to the group of people to which the repertoire belongs, such as professional or religious guild, societal groups and age groups. The chant types have unique vocal techniques that are identified by experienced listeners, especially with the cultural sub-group for which they were originally created.

Poetics forms in feature mode according to (Ọlátúnjí 1984) or speech mode according to (Ògúndèji 2000) include oríkì (panegyric poetry), ẹsẹ Ifá (Ifá corpus), ọfọ̀ (incantation), Òwe (proverb), àlọ àpamo (riddles), and àrọ̀ (chain poetry). They can be rendered in the mode of day-to-day speech, and also can be chanted, sung and played on the drum or other musical instruments.

The poetic forms under the chanting mode is further classified into two; religious and secular. The religious chants are those that are primarily associated with a divinity and, therefore, have an original religious or cultic function, though they are also used for social purposes by devotees of the divinity or members of the cult or guild of workers which the chants are associated with. Examples are ìjálá, ẹ̀sà egúngún, ìyẹrẹ̀ Ifá, òrị̀à pípè (Șàngó pípe, Ọya pípè, Eșù pípè and Ọbàtálá pípè). The secular chants are used mainly for social ceremonies such as marriage, child naming, chieftaincy installation and house warming. They are not attached to any religion or cult and can be chanted by anybody who is knowledgeable in the art. Rárà, òkú pípe, yùngbà kíkùn ,rárà iyàwó, and ewì ajẹmọ́yàwó belong to this class.

(Adélékè 2008) presents examples of song mode types thus; OrinÀjọdún (festival songs), Orin Àlọ́ (Folktale songs), Orin Ìbejì (songs for the twins), Orin òkú (songs for the dead in form of dirge), Orin eré ọmọdé (children game songs), 
Orin Ệfẹ̀ (songs that are meant to create jokes), Orin Ișę (work songs to reduce stress and fatigue while working), Orin Ònkà (songs used to counting), Orin Òșèlú (political songs), Orin İrẹjú (songs that are meant to send people to sleep or to relax), Orin İgbafẹ́ (songs for recreational purpose), and Orin İfẹ́ (love songs).

Song, however, is an aspect or arm of the oral form of literature. It is a sub-category of oral poetry (Olátúnjí 1985). (Ọpádọtun 2008) also explained that oral poetry can either be pure poetry like İjálá (hunter's chants), Ìyẹreẹ Ifá (Ifá divination poetry), Iwì/Èsà Egúngún (Masquerade chants), Ẹkún İyàwó (Bridal's chant), etc. The second arm of oral poetry is the song mode. The major feature or line of difference between the two branches is that pure oral poetries (chant mode) are majorly chants which most times do not require drumming and dancing. The song mode on the other hand requires musical instruments like ìlù (drums), àtẹ́wọ́ (clapping), șẹ̀kẹ̀rẹ̀, agogo (gong) and other forms of instruments that make melodious sounds. The song mode according to (Ọlátúnjí 1985) is accompanied with musical instruments with rhymes. Examples of poetry in the song mode include Dadakúàdà, Lághálogho, Orin Àlọ́ (folk songs), Orin Ìbejì, Orin Arẹmọ, Rárà, Orin Òǹkà, Orin Ọ̀tẹ, Orin Ogun, Orin Òwe, etc. In a broader sense, (Ọlátúndé 2005) further opined that songs as a form of oral poetry is divided into two parts, namely religious and songs for social functions or secular songs. By implication, songs as a genre of oral poetry also have the features of either a religious or a secular song. Examples of religious songs are: Orin Orò, festival songs, etc., while orin òwe, orin Ogun, orin arẹmọ, orin èfẹe, etc. are examples of secular songs or songs for social functions. However, songs of primary school children which are our focus in this paper are safely categorized also into both religious and social functions songs. It should be noted that one cannot clearly demarcate between religious and secular songs among the Yorùbá people. There are elements of religion in almost everything they do including the orchestration of oral genres. At the same time, many of these oral genres of the Yorùbá draw from a religious corpus; and the performance hinges on their religious belief system (Ajíbádé 2009). It must also be noted that the tone of performance of the songs, is one of the prudent and valid means of distinguishing the genres traditionally (Ilésanmí 2004).

\section{DATA PRESENTATION AND ANALYSIS}

From the very first day of birth of a Yorùbá child, he starts hearing poetry and songs for his delight. It is mostly from the grandmother or older women welcoming the new born by chanting the family oríkì. During childhood, a proper and effective mode of socialization is ensured through the use of songs or other forms of literature. (İsọ̀lá 2010) explains that such songs has as their features essential information meant to ensure a continuity of traditions and customs packed into children's literature. Information about plant and animal life, insightful remarks about the nature of the language, mnemonics for counting and a lot of moral instructions woven into poems, stories, rhymes, lullabies and children songs. When lullabies are sung for children, the baby is not expected to understand the meaning of the words, but the rhythm of the songs and the movement of the singer helped majorly to lull the child to sleep.

As we have rightly pointed out, primary school songs are composed and taught to school children to impart positively into them either morally, academically, spiritually or to give specific formative instructions. Such songs are mostly sung either on the assembly ground, break or play time and closing hour as the case may be. Our attention however is not centered on the rhymes, mode of presentation or melodies of the songs, but the message and the intentions. The period or time of use of each song dictates the choice of song to be used as shown in the following data:

\section{Omo rere lèmi ó yàn o \\ Màá j'ọmolúàbi tó ń múnú àwọn òbí rẹ dùn \\ Omo rere lèmi ó yàn o \\ I choose to be a good child \\ I will be a responsible child that makes his/her parent happy \\ I choose to be a good child}

This type of song is taught to children and sung by them to impact morals in them. It is sung majorly in the morning during assembly hours. It is also used when a child is being corrected to highlight the importance of forsaking bad attitudes and yielding to corrections. The song seeks to identify the positive values embedded in being a well-behaved and good mannered child. The second line of the song states emphatically that it is in being a good child that the parent of such child can be happy. By implication, the parent of an untoward or wayward child in the traditional Yorùbá society can never be happy, especially the mother, hence the adage "ọmọ tó bá dára ni ti bàbá, èyí tí kò dára ti ìyá ẹ̣ ni" (a well-mannered child is of the father, the untoward is of the mother).This piece of primary school children's song is also highlighting the kind of premium the Yorùbá society places on the spirit of "ọmọlúàbí". The spirit of ọmọlúàbí according to (Fálétí 2009) is of utmost importance in the traditional Yorùbá value system. The Yorùbá believe a child or individual whose actions and deeds negate the dictates of "ọmolúàbí" spirit is good for nothing, and morally bankrupt. Such a child or individual can never get the approval of the traditional Yorùbá society.

Another song in line with the point in discourse goes thus:

$$
\begin{aligned}
& \text { Òle alápá má sișé } \\
& \text { Ọlẹ fașo ìyà bora sùn } \\
& \text { Ọle sùn, sùn kò mà jí mọ } \\
& \text { E wá wo ayé ọle ò lóde }
\end{aligned}
$$




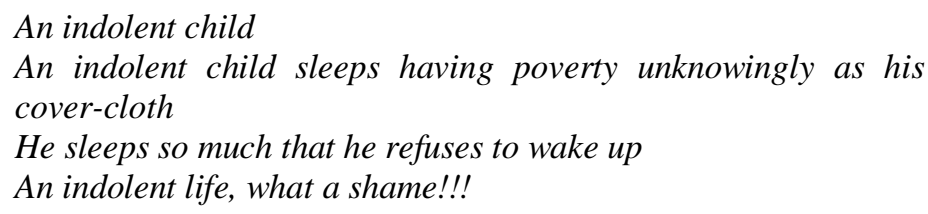

ii.

\author{
Òle fàì roko fài kobè \\ Ó ń reti owó \\ Lái dẹlè f'ộkà t’èèbù bo 'lẹ \\ Ón rúbo òjò \\ Lái șe fàkàfiki fikifàkà \\ Lórí iró, o ó ba níbè o, òfo lo máa ká \\ Tori ohun tá a bá gbin láyé \\ Òn la máa ká
}
An indolent neither till the ground nor make ridges
And he expects to get money
Without weeding the grains or planting tuber crops
Yet offering sacrifices for rain
Having nothing doing attracts no returns
He is bound to reap nothing
For whatever we sow in life is what we will reap.

These songs above as we explained earlier are correctional songs intended to caution school children against indolence and indiscipline. Indolence in the Yorùbá belief system is an act of indiscipline which they frown at in its entirety. Any child of Yorùbá extraction found in such attitude is severely dealt with through verbal abuse in proverbs like "ẹní bí ộle lọ́mọ kò r'ọ́mọ bí" (anyone who give birth to an indolent child has no child) or in songs as in the ones presented above. It could also be in physical punishments like beating.

Another data is presented thus:

$$
\begin{aligned}
& \text { Omo aláigboràn pò nilé ìvé } \\
& \text { Won kò f'etí silẹ sóhun t'ólùkọ kọ́ won } \\
& \text { B'ólùkọ́ wọn bá ń sộộ won á máa șeré } \\
& \text { Won á je je jẹ, won á gb'òdo roboto } \\
& \text { Eré, eré ká șá máa rệrin-ín șá á } \\
& \text { Ișé, ișé iyẹn kil șe tiwọn } \\
& \text { Dòdò àti ráisì kò gbọọ kojá } \\
& \text { Won á jẹ je jẹ, won á gbòdo roboto }
\end{aligned}
$$

\title{
Disobedient children are many in schools \\ They don't pay attention to what teachers teach \\ They play when teachers teach \\ They eat more, and never do well \\ All they do is to play and laugh always \\ Attending to school works is always a problem to them \\ They don't joke with plantain and rice \\ They eat excessively and never do well in academics
}

This song is a take on disobedient and unyielding school children. The song has as its main trust to speak caution and senses into children in that category and to warn them of impending dangers of having such attitude. The Yorùbá society in a bid to inculcate into children their undying love for the spirit and conduct of "ọmọlúàbí, through the formal means (school), drive into children that being negligent to teachers' teachings and instructions is tantamount to self-destruction. They do this using the instrumentality of both formal (school) and informal (songs) means to teach this to children from the formative primary school years that listening to teachers, parents and societal instructions is a virtue of inestimable value. The song equally itemizes the aftermath of being unyielding and disobedient like not doing well academically and morally which is expected to incur the wrath of teachers, parents and the society at large. This in fact could spell doom for the future of such child if nothing is done to avert imminent backwardness through other means which could be physical of spiritual.

The song below is equally correctional in composition, but more factual in pointing out the benefits and at the same time dangers or aftermath of not having western education:

$$
\begin{aligned}
& \text { Bàtà rẹ á dún ko ko kà } 2 x \\
& \text { Bí o bá kàwé rẹ }
\end{aligned}
$$




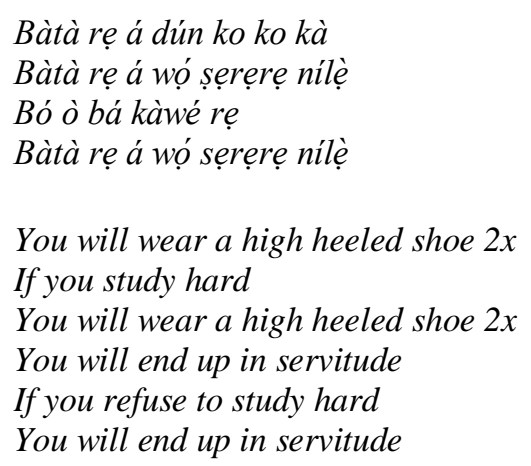

This song was born out of the perception of the superiority of having western education as passport to a good and rewarding life. The type of education introduced to the newly westernized Africa/Yorùbá society of the time overrated the importance of formal education. The type of mentality about education sold to the Yorùbá society of the time pays too much of attention on formal education. It relegated other forms like the informal and semi-formal skills, form of financial education or empowerment. Due to the advent of civilization, the Yorùbá society at that time see farming, trading, art and craft and other informal and semi-formal forms of trade and empowerment as nothing to write home about. With this mentality, parents, teachers and African society as a whole believe in totality that nothing good can ever come from a child that does not have westernized form of education; hence, the composition and conclusion in the above data.

However, the above song can be said to be the true reflection of that time, reason being that the educated are the movers and the shakers in the society of the time. They were trained as teachers, engineers, lawyers, medical doctors among others with the expertise to handle the political, educational and formal sectors. They dictate the larger part of the economy. English language became the language of education and instruction, and by implication, the official language. For anyone to be proficient in the official language, one must have gone to school for formal education. More so, people in the informal sector were made subject of ridicule as a result of their inability to speak the supposed superior 'white man's language'. The educated became models and dominated the middle class of the economy.

The next set of data focus on primary school songs as an instrument of teaching and giving instructions on sanitation, personal hygiene and eating of balanced diet.

i.

$i i$

iii

$$
\begin{aligned}
& \text { Jí ko rorín } \\
& \text { Wè kí o mọ } \\
& \text { Gé èèkánná rẹ } \\
& \text { Fo aṣo rẹ } \\
& \text { Jẹun tó dára lásikò } \\
& \text { Má jẹn jù } \\
& \text { Só o gbó? }
\end{aligned}
$$

Wake up and brush your teeth

Bath and be clean

Trim your nails

Wash your cloths

Eat balanced diet on time

Don't eat too much

Understood?

İmọtótó ló lè sẹgun àrùn gbogbo $2 x$

Imótótó ilé

Imọtótó ara

Imọótótó oúnje

Atáyiká ẹni

İmọtótó ló lè sẹgun àrùn gbogbo.

Cleanliness is the antidote to all sicknesses $2 x$

Cleanliness of the house

Cleanliness of the body

Cleanliness of food we eat

And that of the surroundings we live in

Cleanliness is the antidote to all sicknesess

Èyin omọdé 


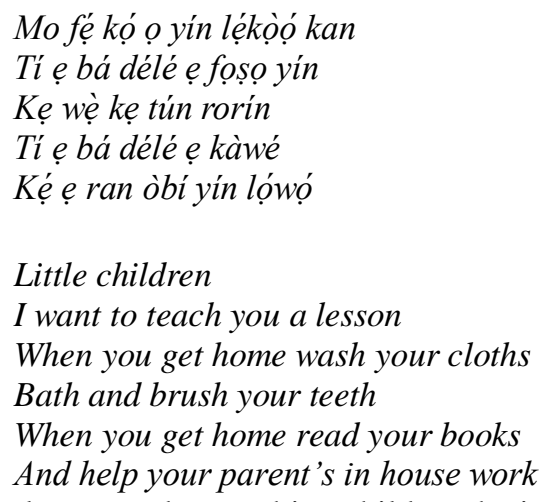

The data above are directly targeted at teaching children the importance of sanitation and personal hygiene. The first song presented in this category is a pointer to the fact that healthy living through regular taking of bath, trimming of the nails and eating of balanced diets are very imperative and key to healthy life and the cardinal points of personal hygiene. The song seeks to indoctrinate children into these good habits that should be promoted as they grow into adulthood. In most cases, children of primary school age are found of not taking personal hygiene so seriously, especially in public primary schools. Teachers and the society noticing this menace, made it as a point of duty to discourage the act through the use of children's songs, because of the imminent dangers of frequent sickness and illnesses associated with not taking proper care of one's body, hence the composition of the songs.

The last line of the first song highlights the dangers associated with excessive consumption of food common to children population. Children are naturally born with excessive interest in consumption of food. Such attitude to the Yorùbá should be discouraged right from childhood not only for its health implications, but also for its social and societal implications if not properly managed or bridled. Children who have excessive interest in food consumption most time become gluttonous. Gluttony leads to selfishness and greed which are unhealthy social practice the Yorùbá society frowns substantially at.

The second song in this category is also a testament to the fact that the Yorùbá society admits that personal hygiene and sanitation of the environment are key to healthy living. The message of the first and second song is the emphasis on environmental sanitation. Sweeping and mopping of the floor, clearing of bushes around the house, cleaning of drainage and water ways, proper washing and disinfecting of toilets, washing of one's hands regularly among others are the basic doctrine of sanitation. The aforementioned are specially stated in this particular song to enlighten school children of its importance. The song does not also leave out the indispensability of cleanliness of the food, vegetables, water and fruits children should eat. It highlights that as we take good care of the body and our environment, it is also imperative to be careful of the type of food we eat and ensure its cleanliness and nutrient quality.

The third song in this category is intentionally composed to specifically point out to children that apart from personal hygiene, sanitation and reading of their books, it is also necessary for them to help their parents in whatever they do; be it house chores, looking after their younger ones or in their line of occupation. It should be born in mind that the Yorùbá society of those years was characterized with farming, craft, semi-skilled occupations and trading (Ògúnjìnmí 2019). Children from such homes are expected to help their parents in the advancement of their occupation and the expansion of their means of generating income which in turn will help in the general upkeep of the children and aid to offset the financial burden of sponsoring children in school.

The next sets of data are composed to fit a particular period of time, for leisure and to relax children's muscles. Such songs are designed to cheer them up, relax their minds and for them to be rejuvenated. The songs most times are sung during break time, play time, closing time or at twilight.

$$
\begin{aligned}
& \text { Tísà jọwọ mo fẹ lọ wá nǹkan jẹ } \\
& \text { Omo oníresi ti dé, obẹ rẹ sì ń ta sánsán } \\
& \text { Àdùké, Alàké, omo oniresì ti dé } \\
& \text { Ó ń șojú rẹdẹrédẹ, e fẹran sọ́bẹ wa }
\end{aligned}
$$

\section{Teacher, please it is time to eat}

The rice seller is here and the aroma of her stew smells nice

Adùkẹ Alàké, the rice seller is here

The sight of the stew looks nice; please add meat to my stew

The lyrics of a song like this sounds comical to children and by implication bound to make them happy. The pleasure of going to eat coupled with the fact that the teacher at that time will give express permission to go for food is a thing of joy. The lyrics or the melody of the song of this nature is of importance, it is intended to make children happy and relax their muscles therefore pointing to the potent power of oral literature as a source of relaxation.

Another example goes thus:

$$
\begin{aligned}
& \text { Lábẹ igi òrom̀bo } \\
& \text { Ibẹ la gbé ń șeré wa }
\end{aligned}
$$




\author{
Inú wá dùn \\ Ara wá yá \\ Lábẹ igi òrom̀bó \\ Under the orange tree \\ That is where we play and relax \\ We are always happy \\ And delighted at heart \\ Under the orange tree
}

This type of song is used mainly during break time or at twilight for children night entertainment. Songs of this nature are used as prelude to folktales mostly sung in the process of waiting for children from other compounds who are regular listeners or participants in folktales at moonlight. (İsọlá 2010) pointed this out that folktales are rich sources of night entertainment and there are folktales for every conceivable moral lesson. In this regard, folktales immensely accelerate the process of socialization because they create unique occasion for moral lessons that might not occur so frequently in normal life. Folktales also introduce children to the socio-political issues of the society because the

$$
\begin{aligned}
& \text { A kí yín olukeó wa } \\
& \text { Àkókò tó láti lọ } \\
& \text { Òbí wa ń dúró dè wá } \\
& \text { A fẹ lọ'lé } \\
& \text { Ó dìgbóse la kí yín } \\
& \text { K'ólórun sọ gbogbo wa } \\
& \text { Ká tún pàdé pẹláyọ } \\
& \text { Lówùrọ òla }
\end{aligned}
$$

We greet you our teacher

It is time to depart for our houses

Our parents are awaiting our arrival

We want to go home

Till we see again is our greetings

May God keep us all

So we can meet with joy

By tomorrow morning

This is another comical type of primary school children's song composed to make them happy and refreshed in readiness to go home. The moral lesson hidden in this song is pointing to the fact that parents are at home awaiting the return of their children from school. Many school children are of the habit of not going home straight to their parents after leaving school. They prefer to go to places they can have fun and engage in rough plays since they will be free from supervision. Aftermath of such actions most times result in the undesired like hooliganism, pilfering, bad influences from street children, thuggery and other social vices. Children who are found of such habits most time get home late with thorn uniform; get involved in street and petty fights and by that sustaining various degrees of injury, become rascals, among others. The third line of this song is admonishing children to go home straight to their parents who must have been expecting their early return from school.

There are also examples of songs taught to primary school children to learn the Yorùbá counting system (ònkà). The use of mnemonics is prevalent with such songs, below is a practical example:

$$
\begin{aligned}
& \text { Ení bi ení } \\
& \text { Èji bi èji } \\
& \text { Éta ̀̀ tagbá } \\
& \text { Érin wọrọkọ } \\
& \text { Arún là á kawọ } \\
& \text { Èfà ni tèlé } \\
& \text { Eje bi èje } \\
& \text { Olúgbọ́n șorò ó kìje } \\
& \text { Èjo bi èjo } \\
& \text { Jíjo là á jo eni tó bíni } \\
& \text { Ẹsán bí ẹsán... }
\end{aligned}
$$

One by one

Two by two

Three sounds like a tap on the calabash

Four is crooked

Counting is done in units of five 


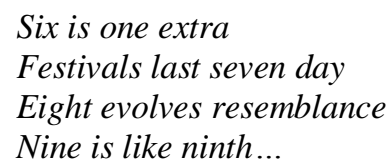

There are also tongue twisters in the Yorùbá language giving valuable practice in correct pronunciation of Yorùbá words. It is always a source of fun but also effective in language teaching and learning.

$$
\begin{aligned}
& \text { Òbo ń gb'ớbo bògbẹ } \\
& \text { Okiti ọbo bọbo lẹnu } \\
& \text { Bó ò bá tẹtè gb 'ọbo bògbé } \\
& \text { Òbo ó gbé o bògbé }
\end{aligned}
$$

Primary school songs do play a servicing and monitoring role to all other aspects of culture in traditional Yorùbá society. For instance, it plays a servicing and monitoring role in religion. Prior the advent of slave trade, civilization and introduction of Christianity which brought Western education, songs are taught to children highlighting the main attributes of each deity. Many of such songs are woven into corpus of praise poetry and rendered on each worship occasion in either song or chanting mode dedicated to the deity. In this way, many barren women are confirmed to get children from deities like Ọșun, Ọbà, Ọya, Ifá etc. There are several instances where children are seen singing and running after Egúngún during the festival, especially those known for dancing (Ọlábímtán1975). Such songs are not just for entertainment, they also play servicing and monitoring roles. Annual festivals are celebrated with captivating chants and songs. Often, these songs play cleansing role for the community (İsọ̣lá 2010). In this way, school children’s songs moderate the contact between man and God.

Still on religion, formal education is synonymous with Christianity. Formal education became prevalent and celebrated in Yorùbá society largely as a result of the advent of Christianity (Ògúnjìnmí 2019). Christianity is a religion formed largely on the basis of songs (Àjùlọ 2014). Every aspect of Christian worship has specially composed songs to complement the moment and message especially in orthodox churches like Catholic, Anglican, and Methodist etc. (Ògúnșínà 2009).Prior the advent of Christianity, Ifá worship was the most prevalent form of religion in the Yorùbá society. (Àjàyí 2005) gave credence to this when he asserts that "It is not just a coincidence that Ifá is the most universal divinityamong the Yorùbá and other West African people”. As a result of the new Christian faith, many people of Yorùbá society who showed interest in sending their children to school had to convert from African Traditional Religion (ATR) to Christianity for them to enjoy the benefit of getting formal education (Ògúnșínà 2009). Many had their names changed from having affiliations with Yorùbá deities like Ògún, Oya, Ifá, Șàngó etc. to names associated with Christian faith before they were admitted into schools. Implicationally, many songs that have been in existence in the traditional Yorùbá society had to be changed to accommodate Christian themes, messages and the name of Jesus. Attacks were launched against the African traditional religion and everything that has to do with it was regarded as idolatry Goldmann (1977) and (Ògújìnmí 2019). Our argument in this session of the paper so far is to identify reasons why Christian themes, lyrics or mode of composition and rendering of some primary school children's songs had to be woven around Christian religion and theme in the Yorùbá society as the following data shows thus:

Ó dòwúrọ òla, kí á sùnre

Kí áńgélì Olúwa sọ́ gbogbo wa
Láyọ láyọ là ń lo lé $2 x$
K’Ólúwa sówa pọ

Till tomorrow, may we sleep well

May the angel of the Lord protect all of us

We depart for our houses in joy $2 x$

May the Lord protect all of us

(ii)

\author{
Amí relé ò baba \\ Olọjọ́ òní o bàbá \\ Gbogbo ẹkọ tí a ti kọ \\ Ninú ilé ìvé wa \\ Má șe jẹ ki eye èșù \\ Kó șá won jẹ lọkàn wa \\ Amín o àmín àsẹ
}

We are set to go home Father Lord

The creator of the day Lord

May all we have been taught

In our school

Not fall on deaf ears

Amen and amen 


\author{
A ki yín olukoọ wa \\ Akókò tó láti lo \\ Òbí wa ń dúró dè wá \\ A fẹ́ lo 'lé \\ Ó digbóṣe la kíyín \\ K’ólórun sọ́ gbogbo wa \\ Ká tún pàdé pẹláyọ \\ Lówùrọ ọla
}

We greet you our teacher

It is time to depart for our houses

Our parents are awaiting our arrival

We want to go home

Till we see again is our greetings

May God keep all of us

So we can meet with joy

Tomorrow morning

(iv)

\author{
Èyin omodé ẹmás kộbáwí \\ İbáwí ló mà lérè \\ Yára șoótó \\ Ko èké silè \\ Eké yen ló pa Ananáyà \\ Àti Sáfírà aya rẹ
}

Children don't be adamant to corrections

Corrections have sweet rewards

Learn to say the truth

Don't be deceptive

It was deception that led to the death of Ananias

And Sapphira his wife

The songs composers displayed much of their native intelligence to combine native and cultural knowledge with that of the bible for easy consumption of school children. As it was in the African traditional religion, the people of Yorùbá society are largely emerged in religion. They are already used to handling over things to the hands of God for guidance and to achieve success. This was largely demonstrated in the above data as the songs seem to introduce and inculcate in children the Christian beliefs. They also used the songs to make a type of supplication to avert the unforeseen and uncertainties about life.

The above data has explained earlier are composed and rendered with Christian themes and tone. They were composed and sung in replica to the commonly used English hymns popularly known as S O P (Songs of Praise). The songs were sung on the assembly ground before the commencement of the day's work, before lunch break and at closing time before school children disperse for their homes. These songs, in addition to giving specific instructions, teach morals, resilient skills, values, history, language etc. was also intended to teach biblical stories, indoctrinate children into Christian values and Christian faith as shown in datum (iv) above.

\title{
V. CONCLUSION
}

From our discussion, it has been established among others that primary school songs serve as agent of teaching moral and religious lessons to school children. Evidences from available songs prove that teaching songs to Yorùbá primary school children is a major source of sustenance and development of Yorùbá culture. It is evident that Yorùbá sociocultural communities thrived and survived as a result of meeting their daily needs and most especially by guaranteeing continuity through effective process of children socialization which ensures that the ideas, norms, values and symbols of their society were internalized into the younger generations through songs and other forms of oral literature.

\section{REFERENCES}

[1] Adétùgbọ́, A. (2001). African Continuities in the Diaspora; Lagos: Center for Black and African Arts and Civilization. National Theatre.

[2] Adeyemí, L. (2006). Tíórì Lítíréșob Ní Èdè Yorùba. İjẹbú-Òde: Shebíotimọ Publications, Nigeria.

[3] Adeyemí, L. (2013). Children's Literature and Yorùba Literary Disability Criticism: İbàdàn: Matrix Publications Nigeria Limited. 
[4] Afọlábí, J.A. (2000). 'African Oral Performance and Functional Aesthetics' in ÌS.E.4S.E: İbàdàn Journal of Folklore Vol. 2, Nos.1\&2. pp. 8-15.

[5] Àjàyí, A. (2005). The Concept of Culture in Àjàyí, A. (ed.) African Culture and Civilization. İbàdàn: Atlantis Books.

[6] Àjùlọ, O. (2014). İmọ İjìnlẹ Èro Yorùbá Nínú Orin Olúbùkọ́lá Ọlọ́mọ́là (a.k.a) Bàbá Àrà. M.A. Thesis, Èkìtì State University Adó-Ėkìtì.

[7] Akporobaro, F.B.O. (2005). Introduction to African Oral Literature. Lagos: Princeton Publishing Company.

[8] Barber, K. (1980). 'Ẹkún İyàwó: Bridal Chants' Olátúnde Ọlátújí (ed.) Readings in Yorùba Chants, (published) mimeograph, pg 217-263

[9] Fádípẹ̀, N. A. (1970). The Sociology of the Yorùbá; Ìbàdàn: University Press.

[10] Fálétí, A. (2009). "Ọmọlúàbí: The Golden Attribute of a Yorùbáman", in Ògúndèjì P.O \&Àkàngbé A. (eds.) Omọlúàbi: Its Concept and Education in Yorùbáland. Ìbàdàn: İbàdàn Cultural Group, 113-128.

[11] Goldmann, L. (1977). Towards a Sociology of the Novel; London: Tavistock Publications Ltd.

[12] (https://www.marriamwebster.com Monday 16/12/2019).

[13] (http://www.dictionary.com Monday 16/12/2019).

[14] Ilésanmí, T.M. (2006). Yorùba Orature and Literature: A Cultural Analysis.

[15] İsọ̀lá, A. (2010). Making Culture Memorable, Essays on Language, Culture and Development; İbàdàn : Hope Publications Ltd.

[16] Ògúndèjì, P.A. (2000). 'Yorùbá Oral Poetry Classification: A case of unity in Diversity' in İSE.4S.E: İbàdàn Journal of Folklore Vol. 2, Nos.1\&2. pp. 26-35.

[17] Ògúnjìnmí, I. B. (2019). İmọ̀ İjìnlẹ-Ėrò Yorùbá Nípa Àșà Ìgbéyàwó: Àgbéyẹ̀wò İtàn Àròsọ Ó Le Kú, Òkèlè Àkọ́bù àtị Ọmọ T'ệkùn Bí. M.A. Thesis, Ekìtì State University Adó-Èkìti.

[18] Ògúnșínà, B. (1987). "The Sociology of Yoruba Novel”. Doctoral Thesis, University of Ìbàdàn, İbàdàn.

[19] Ògúnșínà, B. (2006). Sociology of the Yorùbá Novel: An Introduction. Ìlọin: Integrity Publications.

[20] Obáfẹ́mi, O. (1997). Literature and Society on the border of Discourse; Inaugural Lecture, University of Ìlọin.

[21] Ọlátúnjí, O.O. (1985). Features of Yorùbá Oral Poetry; Ìbàdàn: University Press Limited.

[22] Ọpádọtun, O. (1998). Àșàyàn Àlọ́ Onítàn. İbàdàn: Y-Books.

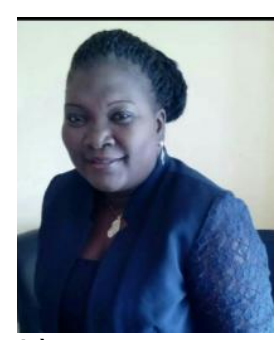

Omobola Agnes Aladesanmi was born in Ile- Oluji in Ondo State over five decades ago. She hails from Ado - Ekiti in Ekiti State, Nigeria. She had her Bachelor of Arts degree in Yoruba Studies from Ondo State University (now Ekiti State University) Ado - Ekiti in 1992. She obtained her Masters of Arts in Yoruba Language from University of Ilorin, Kwara State in 1999 and her PhD in Yoruba Literature from Ekiti State University, Ado - Ekiti in 2012.

She is currently an Associate Professor with Ekiti State University, Ado -Ekiti in the Department of Linguistics and Nigerian Languages. Her publications are both in local and International journals among which are: Aladesanmi O.A. (2017), Silence as a Means of Communication among the Yoruba. Inquiry in African Languages and Literatures, No. 10. Pp. 102-108; Aladesanmi O.A. (2018) Yoruba Ethical Values in Àdìitu Olódùmarè: A Philosophical Appraisal. Journal of Contemporary Research in Humanities \& Social Sciences. RUWAZA AFRIKA. Pwani University, Kilifi, Kenya and Aladesanmi O. A. (2019): Colonization and Cultural Values of Yoruba People: A Case of Traditional Drums in Yoruba Land. In Journal of Language and Literature. Universitas Sanata Dharma, Indonesia.

Dr. Aladesanmi is a member of Professional societies like Yoruba Studies Association of Nigeria; Linguistic Association of Nigeria, Egbẹ Akọmọlede ati Așa Yoruba among others. 